\title{
EFFECT OF LIGHT SOURCE AND DIETARY ENERGY LEVEL ON CARCASS CUTS DISTRIBUTION OF BROILER CHICKENS
}

\author{
Nematallah G.M. Ali; A.I. El-Faham and M.A.M. Abdelaziz \\ Poultry Production Department, Faculty of Agriculture, Ain Shams University, Egypt. \\ Corresponding author: Mrwan Abdelaziz; E-mail: mrwanabdelaziz@agr.asu.edu.eg
}

(Received 1/8/2017, Accepted $19 / 9 / 2017)$

\section{SUMMARY}

$\mathbf{T}$ he present trial aimed to study the effect of light source and dietary energy level on some carcass cuts distribution of male and female broilers. One hundred and eighty one-day-old, male and female, Hubbard broiler chicks, were distributed in a factorial design. Experimental treatments were assigned by applying 3 metabolizable energy (ME) levels [standard recommendation (SR); SR + 100 $\mathrm{kcal} / \mathrm{kg}$ diet and SR $+200 \mathrm{kcal} / \mathrm{kg}$ diet, for both starter and grower feeding phases], and 2 light sources [fluorescent; light-emitting diodes, LED] in 6 treatments, 3 replicates per treatment and 10 birds / replicate. The results indicated that all composition parameters of breast, thigh and drumstick (skin and subcutaneous fats, muscles and bone percentages), were not significantly affected by different dietary energy levels, light sources or bird sex. Additionally, there were no significant differences between treatments on skin and subcutaneous (SC) fats distribution of carcass parts, but LED had increased fats percentages than fluorescent. In addition, this parameter increased with birds fed medium level of dietary energy than other treatments. Furthermore, there were no significant differences between fluorescent and LED treatments or bird sex on muscles percentage of carcass parts, but there were significant differences between dietary energy levels. In addition, chicks fed high dietary energy diets had significantly higher percentages of drumstick muscles. Likewise, there were no significant differences between treatments on bone percentages of carcass parts, but LED decreased total percentage compared with that of fluorescent. Also, mid and high dietary energy level decreased total percentage of bone distribution compared with that of the low dietary energy. Overall results of the present trial, declared that LED light source and low dietary energy had improved carcass composition compared to other treatments. Therefore, it could be advice to use LED lighting in farms to reduce costs of broiler production and to improve physiological status of birds.

Keywords: LED - fluorescent - energy levels - carcass tissue distribution - bird sex

\section{INTRODUCTION}

Increasing energy costs in poultry industry is mainsprings for broiler producers to find ways to minimize the production costs. Additionally, many authors had studied the effect of light on poultry for last three decades. Light is a significant factor in broiler production that composed of three features; wavelength, light intensity and photoperiod. Also, many researchers had known effects of light on activity and reproduction of poultry (Firouzi, et al., 2014). Because light is a powerful factor controlling of many physiological and behavioral processes, many kinds of lights have been introduced commercially and light-emitting diode (LED) light are much more energy efficient and provide adequate illumination (Garrett, 2005). Therefore, many poultry producers have switched form incandescent or fluorescent lamps to LED lighting devices. Thus, conventional light-based systems are being limited, and replaced gradually with LED light systems.

Using LED lamps, as an economical unicolor light source, would encourage broiler production, which is important to broiler producers, because using LED lamps, would reduce electricity consumption (Halevy, et al., 2006). Many types of LED lamps are currently available commercially. The major benefits of these lamps are high efficiency, long operating life, water resistance, single peak of light wavelength, which are characterized by a narrow half band output, and availability in different monochromatic wavelengths (Rozenboim et al., 1998).

Hence, the use of LED lamps in poultry farms is apparently, advantageous because of its energy efficiency and long life, compared to traditional light sources (Parvin et al., 2014). Furthermore, seven- 
day male broiler chickens presented better feed conversion under LED lamps than males at the same age under compact fluorescent lamps (Mendes et al., 2013). On the other hand, cost of feeding is the most significant expensive constiten in poultry production and reaches about $60-70 \%$ of total costs of production (Wilson and Bayer, 2000) and dietary energy itself, contributes about $70 \%$ of the feed cost (Saleh et al., 2004).

Dietary metabolizable energy (ME) level, in broiler diets, presents the most important nutrient required from the standpoint of total cost and quality of broiler diets. Other reports stated no significant differences in carcass characteristics for chicks fed diets with different ME or protein levels, with constant energy-to-protein ratio (Hidalgo et al., 2004; Kamran et al., 2008). Moreover, there were no significant differences in breast, thigh percentages or liver or heart relative weights, due to different dietary treatments.

Results of Selim et al. (2016), concluded that percentage values of breast meat yield, thigh, drumstick and breast drip loss, were significantly increased by reduction in dietary ME level (E100 or E150) compared with standard strain recommendations. However, El-Faham et al. (2015) reported that live body weight, feed intake, feed conversion ratio and some carcass characteristics were not affected by interaction within (ME) levels and housing system (floor pens and cages). Few reports have focused on the interaction within type of lighting, dietary energy levels, and bird sex on carcass traits and tissue distribution of broilers. Therefore, the aim of this study was to evaluate changes of carcass traits and tissue distribution of male and female broilers, reared under different light sources, and fed different dietary energy levels.

\section{MATERIALS AND METHODS}

This study was conducted at Agricultural Experiments and Researches Station at Shalakan, Poultry Production Experimental Unit, Faculty of Agriculture, Ain Shams University, Egypt. A total number of 180 one-day-old Hubbard broiler chicks were allocated on six treatments, 3 replicates per treatment and 10 birds/ replicate. Equal number of males and females was allocated within each treatment.

\section{Experimental design:}

In a factorial design [ $2 \times 3 \times 2]$, male and female broilers ( 2 sexes), were examined by 3 levels of metabolizable energy [standard recommendation (SR), 100 and $200 \mathrm{Kcal} / \mathrm{Kg}$ diets higher than (SR)] for each feeding phase (starter and grower), and 2 sources of light [fluorescent lamps and light-emitting diodes (LED) lamps].

\section{Experimental diets:}

Chicks were fed on corn-soybean meal based diets during starting (0-3 weeks) and growing (4-5 weeks) periods as described in (Table 1). Standard diets were formulated to be $2912 \mathrm{Kcal} / \mathrm{Kg}$ with $23 \%$ $\mathrm{CP}$ and $3032 \mathrm{Kcal} / \mathrm{Kg}$ with $21 \% \mathrm{CP}$ during starting and growing periods, respectively. All birds were fed experimental diets ad-libitum and had access to water until the end of experiment.

\section{Light sources:}

Chicks were reared under continuous lighting throughout the experiment in two separate rooms; one of them was for LED groups, and the other was for fluorescent groups. Light intensity at the head level of the birds ranged from 40 to 42 lux, for LED and fluorescent lighting, respectively. Intensity of light was measured by handheld digital solar power meter TENMARS ${ }^{\circledR}$, model TM-206 (0 to $1999 \mathrm{~W} / \mathrm{m} 2$ or 634 $\left.\mathrm{BTU} / \mathrm{ft}^{2} * \mathrm{~h}\right)$.

\section{Housing of birds:}

All chicks were kept under similar hygienic conditions and were vaccinated against mutual diseases. Floor brooders with gas heaters were used for rearing chicks in two separate rooms. Three groups treated with LED lighting were kept in the first room, and the other three groups treated with fluorescent lighting were kept in the other room.

\section{Slaughtering and carcass characteristics:}

At the end of experiment ( 5 weeks of age), six birds ( 3 males and 3 females) of each treatment around the average live body weight of corresponding treatment were slaughtered and eviscerated. Carcasses were 
stored at $\left(-20^{\circ} \mathrm{c}\right)$ prior to cutting and dissection. Carcasses were thawed for about 8 hours at $1^{\circ} \mathrm{C}$. The right-body sides were then separated into commercial cuts; thigh, drumstick, and breast.

In each cut, skin, subcutaneous fat, muscle and bone were separated and weighed. The sum of muscle and intramuscular fat formed the lean. Sum of those parts over all cuts gives the total lean, total bone and total skin plus subcutaneous fat for a single side.

\section{Statistical procedures:}

Data were analyzed through three-way analysis of variance with light source (L), dietary energy level (E), sex of birds (S) and their interactions using the General Linear Model (GLM) procedure of SAS (2002) as the following model:

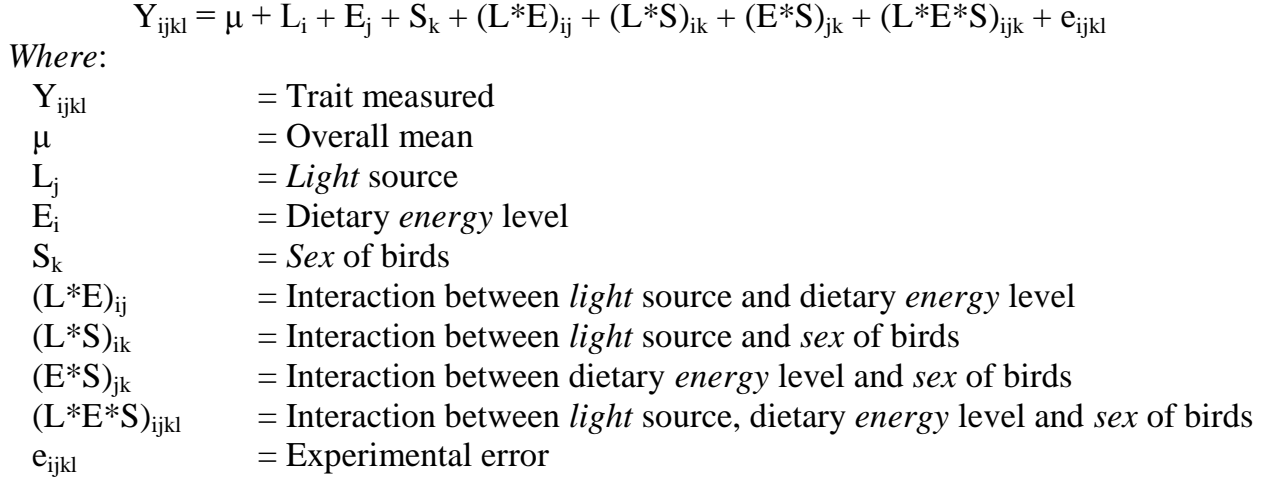

When significant differences among means were found, means were separated using Duncan's multiple range tests (Duncan, 1955).

Table (1): Calculated chemical analyses of experimental diets:

\begin{tabular}{|c|c|c|c|c|c|c|c|}
\hline \multirow{3}{*}{ 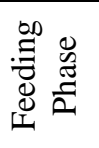 } & Items & 1 & 2 & 3 & 4 & 5 & 6 \\
\hline & Energy Level & Low & Mid & High & Low & Mid & High \\
\hline & Lighting Type & \multicolumn{3}{|c|}{ Fluorescent Light } & \multicolumn{3}{|c|}{ LED Light } \\
\hline \multirow{6}{*}{ 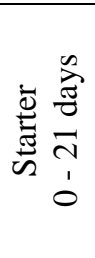 } & Crude Protein $\%$ & 23.00 & 23.00 & 23.00 & 23.00 & 23.00 & 23.00 \\
\hline & $\mathrm{ME} \mathrm{Kcal/Kg} \mathrm{diet}$ & 2912 & 3006 & 3100 & 2912 & 3006 & 3100 \\
\hline & Calcium $\%$ & 1.00 & 1.01 & 1.01 & 1.00 & 1.01 & 1.01 \\
\hline & Available Phosphorus \% & 0.50 & 0.50 & 0.50 & 0.50 & 0.50 & 0.50 \\
\hline & Lysine \% & 1.40 & 1.40 & 1.40 & 1.40 & 1.40 & 1.40 \\
\hline & Methionine \& Cysteine \% & 1.07 & 1.07 & 1.07 & 1.07 & 1.07 & 1.07 \\
\hline \multirow{6}{*}{ 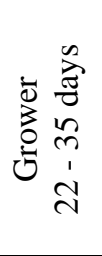 } & $\mathrm{CP} \%$ & 21.00 & 21.00 & 21.00 & 21.00 & 21.00 & 21.00 \\
\hline & $\mathrm{ME} \mathrm{Kcal/Kg} \mathrm{diet}$ & 3032 & 3126 & 3220 & 3032 & 3126 & 3220 \\
\hline & Calcium $\%$ & 0.90 & 0.91 & 0.91 & 0.90 & 0.91 & 0.91 \\
\hline & Available Phosphorus \% & 0.45 & 0.45 & 0.45 & 0.45 & 0.45 & 0.45 \\
\hline & Lysine \% & 1.26 & 1.26 & 1.27 & 1.26 & 1.26 & 1.27 \\
\hline & Methionine \& Cysteine \% & 0.98 & 0.98 & 0.98 & 0.98 & 0.98 & 0.98 \\
\hline
\end{tabular}

ME: Metabolizable Energy

\section{RESULTS AND DISCUSSION}

\section{Breast composition:}

Although there were no significant differences within most treatments (Table 2), LED treatments had increased percentages of skin, subcutaneous (SC) fats and muscles than fluorescent treatments and decreased bones percentage. On the other hand, mid energy had increased percentages of skin, SC fat and muscles, but decreased bones percentage than other treatments (low or high energy). Regardless to sex, naturally females have percentages of skin, SC fats higher than males. 
Muscles percentages were closely equivalent, but bones percentages in males were higher than females. Generally, increased percentages of skin or SC fat and muscles in birds that reared on LED might be attributed to decrease the activity of the birds and subsequently, increased fat $\%$ and muscle growth than that of birds reared on fluorescent treatments.

Additionally, it was noticeable that interaction between type of light and dietary treatment, was observed for skin, SC fats \%. Related reports are somewhat rare and further studies are required to define these interactions. The different light sources or dietary energy levels treatments had a clear effect on the bone tissue development, consequently bone density.

Table (2): Effect of treatments on breast composition.

\begin{tabular}{|c|c|c|c|c|}
\hline \multirow{2}{*}{ Treatment } & & \multicolumn{3}{|c|}{ Breast cuts percentages } \\
\hline & & Skin \& SC Fats \% & Muscles \% & Bones \% \\
\hline Fluorescent & L1 & 7.37 & 47.25 & 45.36 \\
\hline LED & L2 & 8.07 & 48.01 & 43.91 \\
\hline Low Energy & E1 & 7.60 & 46.34 & 46.04 \\
\hline Mid Energy & $\mathrm{E} 2$ & 8.18 & 48.30 & 43.51 \\
\hline High Energy & E3 & 7.39 & 48.24 & 44.35 \\
\hline Male & $\mathrm{S} 1$ & 7.41 & 47.27 & 45.31 \\
\hline Female & $\mathrm{S} 2$ & 8.04 & 47.99 & 43.96 \\
\hline \multicolumn{5}{|c|}{ Probability } \\
\hline Light (L) & & 0.40 & 0.57 & 0.41 \\
\hline Energy $(\mathrm{E})$ & & 0.72 & 0.40 & 0.48 \\
\hline $\operatorname{Sex}(\mathrm{S})$ & & 0.45 & 0.59 & 0.44 \\
\hline $\mathrm{L} * \mathrm{E}$ & & 0.54 & 0.28 & 0.26 \\
\hline $\mathrm{L} * \mathrm{~S}$ & & 0.92 & 0.56 & 0.68 \\
\hline $\mathrm{E} * \mathrm{~S}$ & & 0.97 & 0.43 & 0.62 \\
\hline $\mathrm{L} * \mathrm{E} * \mathrm{~S}$ & & 0.37 & 0.22 & 0.23 \\
\hline
\end{tabular}

L: Light; E: Energy; S: Sex; SC Fats: Subcutaneous Fats

\section{Thigh composition:}

Table (3) indicates that birds that reared on LED treatments have low skin, SC fats \% than birds that reared on fluorescent treatments. The muscles and bones \% were closely equal, but birds of fluorescent treatment had higher score than that of LED treatments. On the other hand, mid and high dietary energy

Table (3): Effect of treatments on thigh composition.

\begin{tabular}{|c|c|c|c|c|}
\hline \multirow{2}{*}{ Treatment } & & \multicolumn{3}{|c|}{ Thigh cuts percentages } \\
\hline & & Skin \& SC Fats $\%$ & Muscles \% & Bones \% \\
\hline Fluorescent & L1 & 10.88 & 49.89 & 40.63 \\
\hline LED & $\mathrm{L} 2$ & 10.27 & 49.10 & 39.23 \\
\hline Low Energy & E1 & 9.78 & 48.12 & 42.09 \\
\hline Mid Energy & $\mathrm{E} 2$ & 11.08 & 49.79 & 39.12 \\
\hline High Energy & E3 & 10.86 & 50.56 & 38.57 \\
\hline Male & $\mathrm{S} 1$ & 9.47 & 50.74 & 39.79 \\
\hline Female & $\mathrm{S} 2$ & 11.68 & 48.25 & 40.07 \\
\hline \multicolumn{5}{|c|}{ Probability } \\
\hline Light (L) & & 0.70 & 0.66 & 0.46 \\
\hline Energy (E) & & 0.77 & 0.53 & 0.29 \\
\hline $\operatorname{Sex}(\mathrm{S})$ & & 0.18 & 0.18 & 0.88 \\
\hline $\mathrm{L} * \mathrm{E}$ & & 0.48 & 0.38 & 0.21 \\
\hline $\mathrm{L} * \mathrm{~S}$ & & 0.17 & 0.79 & 0.17 \\
\hline $\mathrm{E} * \mathrm{~S}$ & & 0.92 & 0.75 & 0.91 \\
\hline $\mathrm{L} * \mathrm{E} * \mathrm{~S}$ & & 0.34 & 0.93 & 0.55 \\
\hline
\end{tabular}

L: Light; E: Energy; S: Sex; SC Fats: Subcutaneous Fats

have increased the skin and SC fats \% and muscles \% than those of low dietary energy treatment, whereas, low dietary energy have increased bones $\%$ than other treatments. Logically, skin and SC fats $\%$ 
were higher in females compare when compared to males, also muscles $\%$ in males were higher than that of females. In contrary, bones $\%$ in males was lower than females. These results are disagreeing with the normal cases. Light increases the physical activity of birds and stimulates bone development, thereby improves the leg health of birds. Thigh muscle \% in males was higher than females because androgens in males enhance protein synthesis and reduce protein breakdown. As a result, androgens cause muscle accretion and are involved in the normal maintenance of muscular tissue. Therefore, light enhances muscle growth (Sturkie, 2015).

\section{Drumstick composition:}

Table (4) indicates the effect of different treatments on drumstick composition. Although the treatments had no significant effects on drumstick composition, but numerically there were some differences between treatments. LED treatments have increased skin and SC fats \%, and muscles \% but decreased bones $\%$. About dietary energy treatments, mid dietary energy had increased skin and SC fats $\%$. On the other hand, high dietary energy had increased muscles \% than other treatments. And, low dietary energy had increased bones $\%$. These treatments decreased skin, SC fats \%, and increased bones $\%$ in females than males. High dietary energy might promote growth of myofiber, which is probably due to the proliferation of skeletal muscle satellite cells and the increase of number of myofibers in light sources group (Halevy, et al., 2006). Manipulation of nutrient density showed an effect on growth performance and carcass quality. Most research found that feeding broilers on diets with lower nutrient density, caused inferior feed efficiency (Wu et al., 2007; Fanatico et al., 2008; Kamran et al., 2008) and no effect on yields of carcass, breast or thigh and abdominal fat (Kamran et al., 2008).

Table (4): Effect of treatments on drumstick composition.

\begin{tabular}{|c|c|c|c|c|}
\hline \multirow{2}{*}{ Treatment } & & \multicolumn{3}{|c|}{ Drumstick cuts percentages } \\
\hline & & Skin \& SC Fats \% & Muscles \% & Bones \% \\
\hline Fluorescent & L1 & 10.16 & 65.82 & 24.01 \\
\hline LED & $\mathrm{L} 2$ & 10.85 & 67.74 & 21.41 \\
\hline Low Energy & E1 & 9.79 & 65.68 & 24.53 \\
\hline Mid Energy & E2 & 11.26 & 66.43 & 22.30 \\
\hline High Energy & E3 & 10.46 & 68.23 & 21.30 \\
\hline Male & S1 & 11.03 & 66.98 & 21.98 \\
\hline Female & $\mathrm{S} 2$ & 9.97 & 66.58 & 23.44 \\
\hline \multicolumn{5}{|c|}{ Probability } \\
\hline Light (L) & & 0.33 & 0.30 & 0.25 \\
\hline Energy $(\mathrm{E})$ & & 0.25 & 0.50 & 0.48 \\
\hline $\operatorname{Sex}(\mathrm{S})$ & & 0.15 & 0.82 & 0.51 \\
\hline $\mathrm{L} * \mathrm{E}$ & & 0.36 & 0.98 & 0.93 \\
\hline $\mathrm{L} * \mathrm{~S}$ & & 0.18 & 0.89 & 0.74 \\
\hline $\mathrm{E} * \mathrm{~S}$ & & 0.52 & 0.32 & 0.36 \\
\hline $\mathrm{L} * \mathrm{E} * \mathrm{~S}$ & & 0.28 & 0.66 & 0.65 \\
\hline
\end{tabular}

L: Light; E: Energy; S: Sex; SC Fats: Subcutaneous Fats

\section{Skin and subcutaneous fats distribution:}

Although there were no significant differences between treatments on skin and subcutaneous fats distribution of carcass parts, but LED treatments had increased the percentage of total skin and Sc fats, as recorded with mid dietary energy, and that of males (Table 5). These results reflected that LED light had decreased the activity of birds and subsequently increased fat distribution of carcass parts. Most research on effects of light program on carcass traits reported that no significant difference between intermittent lighting and continuous lighting in proportions of abdominal fat, wing, thigh and breast (Renden et al., 1996; Chen et al., 2007; Onbasilar et al., 2007).

On the other hand, Li et al. (2010) reported that low-density diets increased percentages of wings and legs and reduced abdominal fat rate. Light program and nutrient density had some effects on broilers. 
Table (5): Effect of treatments on skin and subcutaneous fats distribution.

\begin{tabular}{|c|c|c|c|c|c|}
\hline \multirow{2}{*}{ Treatment } & & \multicolumn{4}{|c|}{ skin \& subcutaneous fats percentages of carcass parts } \\
\hline & & Breast & Thigh & Drum Stick & Total \\
\hline Fluorescent & L1 & 3.29 & 3.01 & 1.52 & 7.81 \\
\hline LED & $\mathrm{L} 2$ & 3.60 & 2.79 & 1.62 & 8.02 \\
\hline Low Energy & E1 & 3.38 & 2.63 & 1.49 & 7.51 \\
\hline Mid Energy & E2 & 3.74 & 3.02 & 1.62 & 8.39 \\
\hline High Energy & E3 & 3.21 & 3.03 & 1.61 & 7.85 \\
\hline Male & $\mathrm{S} 1$ & 3.28 & 2.57 & 1.71 & 8.27 \\
\hline Female & $\mathrm{S} 2$ & 3.61 & 3.22 & 1.44 & 7.56 \\
\hline \multicolumn{6}{|c|}{ Probability } \\
\hline Light (L) & & 0.41 & 0.62 & 0.42 & 0.73 \\
\hline Energy $(\mathrm{E})$ & & 0.50 & 0.68 & 0.66 & 0.52 \\
\hline $\operatorname{Sex}(\mathrm{S})$ & & 0.39 & 0.15 & 0.05 & 0.27 \\
\hline $\mathrm{L} * \mathrm{E}$ & & 0.42 & 0.66 & 0.95 & 0.49 \\
\hline $\mathrm{L} * \mathrm{~S}$ & & 0.72 & 0.16 & 0.13 & 0.27 \\
\hline $\mathrm{E} * \mathrm{~S}$ & & 0.98 & 0.94 & 0.84 & 0.95 \\
\hline $\mathrm{L} * \mathrm{E} * \mathrm{~S}$ & & 0.41 & 0.35 & 0.61 & 0.41 \\
\hline
\end{tabular}

L: Light; E: Energy; S: Sex

\section{Muscles distribution:}

Data in table (6) present the effect of different treatments on muscles distribution. There were no significant differences between fluorescent and LED treatments on muscles percentages of carcass parts, but there were significant differences between dietary energy levels, especially mid and high dietary energy on muscles of drumstick, as the high dietary energy level had increased muscles of drumstick compared with other levels. This might explain that, light source and dietary energy level have increased proliferation of muscle cells (Halevy et al., 2006). Other researchers found that compared with males, females had higher proportion of total muscle in breast and recorded lower fraction of their total muscle in leg (Broadbent et al., 1981; Shahin et al., 1996).

Table (6): Effect of treatments on muscles distribution.

\begin{tabular}{|c|c|c|c|c|c|}
\hline \multirow{2}{*}{ Treatment } & & \multicolumn{4}{|c|}{ muscles percentages of carcass parts } \\
\hline & & Breast & Thigh & Drum Stick & Total \\
\hline Fluorescent & L1 & 21.07 & 13.74 & 9.85 & 44.67 \\
\hline LED & L2 & 21.35 & 13.46 & 10.16 & 44.98 \\
\hline Low Energy & E1 & 20.61 & 12.95 & $9.93^{\mathrm{ab}}$ & 43.50 \\
\hline Mid Energy & $\mathrm{E} 2$ & 22.11 & 13.64 & $9.55^{\mathrm{b}}$ & 45.30 \\
\hline High Energy & E3 & 20.91 & 14.21 & $10.54^{\mathrm{a}}$ & 45.66 \\
\hline Male & $\mathrm{S} 1$ & 20.88 & 13.82 & 10.33 & 45.04 \\
\hline Female & $\mathrm{S} 2$ & 21.54 & 13.38 & 9.69 & 44.60 \\
\hline \multicolumn{6}{|c|}{ Probability } \\
\hline Light (L) & & 0.70 & 0.65 & 0.33 & 0.74 \\
\hline Energy (E) & & 0.22 & 0.27 & 0.07 & 0.17 \\
\hline $\operatorname{Sex}(\mathrm{S})$ & & 0.37 & 0.47 & 0.06 & 0.65 \\
\hline $\mathrm{L} * \mathrm{E}$ & & 0.21 & 0.32 & 0.08 & 0.18 \\
\hline $\mathrm{L} * \mathrm{~S}$ & & 0.66 & 0.71 & 0.44 & 0.86 \\
\hline $\mathrm{E} * \mathrm{~S}$ & & 0.43 & 0.53 & 0.91 & 0.29 \\
\hline $\mathrm{L} * \mathrm{E} * \mathrm{~S}$ & & 0.18 & 0.91 & 0.65 & 0.34 \\
\hline
\end{tabular}

L: Light; E: Energy; S: Sex

\section{Bone distribution:}

Generally, there was no significant difference between treatments on bones percentages of carcass parts (Table 7), but concerning total bones, LED treatments decreased total percentage compared to fluorescent treatments. 
Table (7): Effect of treatments on bones distribution.

\begin{tabular}{|c|c|c|c|c|c|}
\hline \multirow{2}{*}{ Treatment } & & \multicolumn{4}{|c|}{ bones percentages of carcass parts } \\
\hline & & Breast & Thigh & Drum Stick & Total \\
\hline Fluorescent & L1 & 20.19 & 10.77 & 3.59 & 34.56 \\
\hline LED & L2 & 19.48 & 11.13 & 3.23 & 33.85 \\
\hline Low Energy & E1 & 20.45 & 11.30 & 3.72 & 35.48 \\
\hline Mid Energy & $\mathrm{E} 2$ & 19.88 & 10.74 & 3.22 & 33.85 \\
\hline High Energy & E3 & 19.17 & 10.82 & 3.29 & 33.28 \\
\hline Male & $\mathrm{S} 1$ & 20.00 & 10.81 & 3.38 & 34.20 \\
\hline Female & $\mathrm{S} 2$ & 19.67 & 11.10 & 3.44 & 34.21 \\
\hline & & & Probability & & \\
\hline Light (L) & & 0.31 & 0.50 & 0.29 & 0.52 \\
\hline Energy $(\mathrm{E})$ & & 0.33 & 0.64 & 0.42 & 0.26 \\
\hline $\operatorname{Sex}(\mathrm{S})$ & & 0.64 & 0.59 & 0.87 & 0.99 \\
\hline $\mathrm{L} * \mathrm{E}$ & & 0.35 & 0.08 & 0.62 & 0.21 \\
\hline $\mathrm{L} * \mathrm{~S}$ & & 0.15 & 0.25 & 0.85 & 0.14 \\
\hline $\mathrm{E} * \mathrm{~S}$ & & 0.63 & 0.94 & 0.18 & 0.60 \\
\hline $\mathrm{L} * \mathrm{E} * \mathrm{~S}$ & & 0.22 & 0.41 & 0.44 & 0.30 \\
\hline
\end{tabular}

L: Light; E: Energy; S: Sex

Also, mid and high dietary energy decreased total percentages of bone distribution than low dietary energy treatment. Sex had no effect on total percentages of bones of carcass parts.

\section{CONCLUSION}

It can be acquired from the present observations that all studied parameters were not affected by interactions between light sources (fluorescent, LED), dietary energy level (SR, SR+100, SR+200) or bird sex (male, female).And, using LED lighting systems in poultry farms would reduce cost of production and maintain physiological status of birds.

\section{REFERENCES}

Broadbent, L.A.; B.J. Wilson and C. Fisher (1981). The composition of the broiler chicken at 56 days of age: output, components and chemical composition. Brit. Poult. Sci., 22: 385-390.

Chen, H.; R.L. Huang; H.X. Zhang; K.Q. Di; D. Pan and Y.G. Hou (2007). Effect of photoperiod on ovarian morphology and carcass traits at sexual maturity in pullets. Poult. Sci., 86: 917-920.

Duncan, D.B. (1955). Multiple ranges and multiple F test. Biometrics, 11: 1-42.

El-Faham, A.I.; N.G.M. Ali and R.M. Ali (2015). Effect of feeding different dietary energy levels on productive and physiological performance of broiler chicks under different housing systems. Egypt. J. Nutr. Feeds, 2: 301-310.

Fanatico, A.C.; P.B. Piliai; P.Y. Heste; C. Falcone; C.M. Owens and J.L. Emmert (2008). Performance, livability, and carcass yield of slow-and fast-growing chicken genotypes fed low-nutrient or standard diets and raised indoors or with outdoor access. Poult. Sci., 87: 1012-1021.

Firouzi S.; H.H. Nazarpak; H. Habibi; S.S. Jalali; Y. Nabizadeh; F. Rezaee; R. Ardali; and M. Marzban (2014). Effects of color lights on performance, immune response and hematological indices of broilers. J. World's Poult. Res., 4 (2): 52-55.

Garrett, L.V.W. (2005). Using LED light can reduce your electric costs. Appl. Poult. Engin. News. 3: 1 4.

Halevy, O.; Y. Piestun; I. Rozenboim; and Z. Yablonka-Reuveni (2006). In ovo exposure to monochromatic green light promotes skeletal muscle cell proliferation and affects myofiber growth in posthatch chicks. Am. J. Physiol.-Regul. Intergr. Comp. Physiol. 290 (4): R1062-R1070. 


\section{Ali et al.}

Hidalgo, M.A.; W.A. Dozier III, A.J. Davis and R.W. Gordon (2004). Live performance and meat yield responses to progressive concentrations of dietary energy maintained at a constant metabolizable energy -to-crude protein ratio. J. App1. Poult. Res. 13:319-327.

Kamran, Z.; M. Sarwar; M. Nisa; M.A. Nadeem; S. Mahmood; M.E. Babar and S. Ahmed (2008). Effect of low-protein diets having constant energy-to-protein ratio on performance and carcass characteristics of broiler chickens from one to thirty-five days of age. Poult. Sci., 87: 468-474.

Li, W.B.; Y.L. Guo; J.L. Chen; R. Wang; Y. He and D.G. Su (2010). Influence of lighting schedule and nutrient density in broiler chickens: effect on growth performance, carcass traits and meat quality. Asian-Aust. J. Anim. Sci., 23 (11): 1510-1518.

Mendes, A.S.; S.J. Pauao; R. Restelatto; G.M. Morello; De Moura; and J.C. Possenti (2013). Performance and preference of broiler chickens exposed to different lighting sources. Journal of Applied Poultry Research, 22: 62-70.

Onbasilar, E.E.; H. Eroll; Z. Cantekin and U. Kaya (2007). Influence of intermittent lighting on broiler performance, incidence of tibial dyschondroplasia, tonic immobility, some blood parameters and antibody production. Asian-Aust. J. Anim. Sci., 20 (4): 550-555.

Parvin, R., M.M.H. Mushtaq; M.J. Kim and H.C. Choi (2014). Light emitting diode (LED) as a source of monochromatic light: a novel lighting approach for behavior, physiology and welfare of poultry: review. World's Poultry Science Journal, 3: 543-556.

Renden, J.A.; E.T. Moran and S.A. Kincaid (1996). Effect of lighting regimes on lighting programs for broilers that reduce leg problems without loss of performance or yield. Poult. Sci., 75: 1345-1350.

Rozenboim I.; I. Biran; Z.E. Uni; B.O. Robinzon and O.R. Halevy (1998). The effect of monochromatic light on broiler growth and development. Poult. Sci., 78 (1): 135-138.

Saleh, E.A.; S.E. Watkins; A.L. Waldroup and P.W. Waldroup (2004). Effects of dietary nutrient density on performance and carcass quality of male broilers grown for further processing. Int. J. Poult. Sci., 3(1): $1-10$.

SAS (2002). SAS/STAT User, S Guide: Statistics. Ver. 8.2, SAS Institute Inc., Cary. NC.

Selim, N.A.; H.A. Abdel Magied; H.H. Habib; A.H. Waley; A.A. Fadl and S.M. Shalash (2016). Effect of pectinase enzyme supplementation and low energy corn-soybean meal diets on broiler performance and quality of carcass and meat. Egypt. Poult. Sci. J., 36: 319-335.

Shahin, K.A.; S.A. Ibrahim and A.I. El-Faham (1996). The effects of breed and sex on carcass composition and tissue distribution of chickens. Ind. J. Anim. Sci., 66: 504-510

Sturkie, P.D. (2015). Avian physiology Sixth ed. Academic press. San Diego, California. U.S.A.

Wilson, K.J. and R.S. Beyer (2000). Poultry Nutrition Information for the Small Flock. Kansas State University Agricultural Experiment Station and Cooperative Extension Service.

Wu, G.; M.M. Bryant; P. Gunawardana and D.A. Roland (2007). Effect of nutrient density on performance, egg components, egg solids, egg quality, and profits in eight commercial leghorn strains during phase one. Poult. Sci., 86: 691-697. 


\section{تأثير مصدر الإضاءة ومستوي الطاقة بالعليقة على توزيع قطعيات الذبيحة لبدارى التسمين} نعمة الله جمال الدين ححم على، أحمد إبراهيم سليمان الفحام، مروان عبدالعزيز محمود عبدالعزيز قسم إنتاج الأدواجن ـ كلية الزراعة ـ ـامعة عين شمس - مصر.

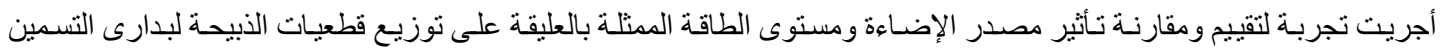

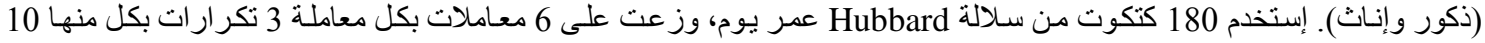

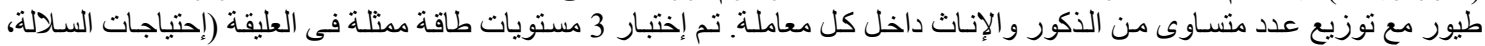

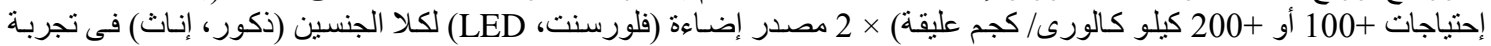

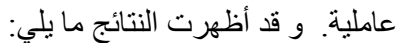

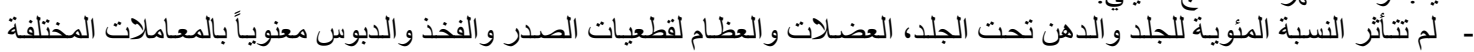

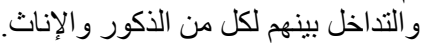

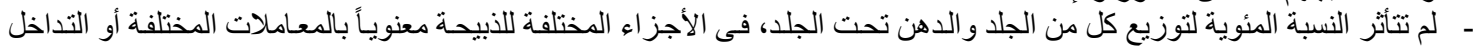

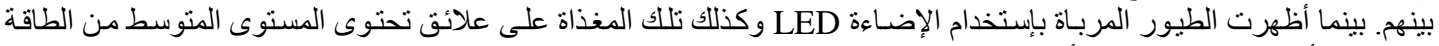

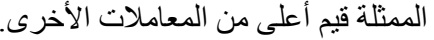

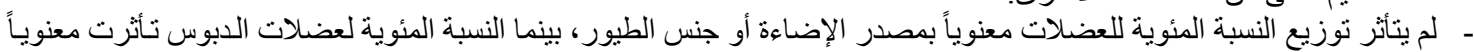

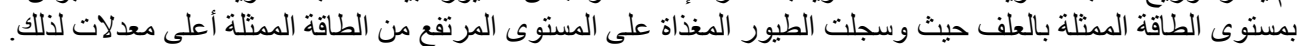

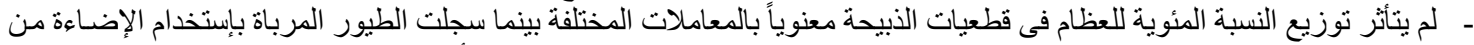

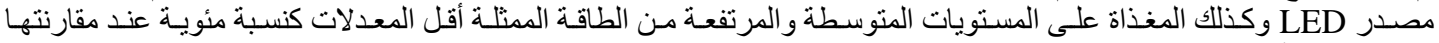
بالمعاملات الأخرى.

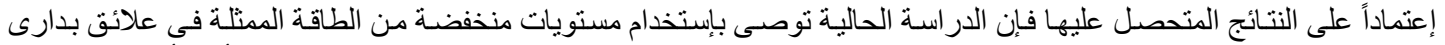

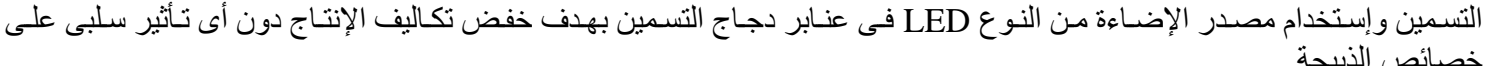

